\title{
Farm-Based Measures for Reducing Microbiological Health Risks for Consumers from Informal Wastewater-Irrigated Agriculture
}

\author{
Bernard Keraita, Flemming Konradsen and Pay Drechsel
}

\begin{abstract}
This chapter presents farm-based measures that have been developed and tested in the informal irrigation sector to reduce microbiological health risks for consumers from wastewater irrigation of vegetables commonly eaten uncooked. The measures target poor smallholder farmers or farmer associations in developing countries as part of a multiple-barrier approach for health-risk reduction along the farm to fork pathway. Measures discussed include treatment of irrigation water using ponds, filters and wetland systems; water application techniques; irrigation scheduling; and crop selection. In addition, the chapter highlights some practical strategies to implement these measures, based largely on field experiences in Ghana. Although most measures discussed do not fully eliminate possible health risks, they can significantly complement other pathogen barriers. Which measures fit, either alone or in combination, will depend on local site characteristics and practices. Further studies are required to develop new measures or adapt them to other irrigation practices and systems in developing countries.
\end{abstract}




\section{INTRODUCTION}

Wastewater-irrigated agriculture is increasingly becoming a common phenomenon, and more so with increasing global water scarcity. Wastewater irrigation creates both opportunities and problems. The opportunities of wastewater irrigation are that it provides convenient disposal of waste products and adds valuable plant nutrients and organic matter to soils and crops (van der Hoek et al., 2002). Wastewater also provides reliable irrigation water and supports urban food supply, especially with perishable crops, making it a source of livelihood for many farmers and produce traders. On the other hand, wastewater irrigation, especially with untreated wastewater, facilitates transmission of diseases from excreta-related pathogens and vectors, skin irritants and toxic chemicals like heavy metals and pesticides. Of most concern in developing countries are excreta-related pathogens and skin irritants (Blumenthal et al., 2000; van der Hoek et al., 2005). These risks affect the sustainability of wastewater irrigation and need to be addressed. This chapter focuses on risk reduction measures for excreta-related pathogens, i.e. microbiological health risks for consumers of increasingly popular salad greens.

For many years, wastewater treatment was seen as the panacea for reducing health risks in wastewater-irrigated agriculture. The WHO, in its 2006 Guidelines for safe use of wastewater in agriculture, reviewed more than 20 studies on removal of various pathogens by different treatment processes (WHO, 2006). The studies show that biological processes, as they take place in pond systems, are especially effective in pathogen removal. Indeed, in many developed and middle-income countries, such as the USA, Tunisia, Spain, France, Israel and Jordan, wastewater is effectively treated before application to agricultural fields (Jiménez and Asano, 2008). In these countries, wastewater irrigation is formal, well regulated and controlled by well-established agencies (McCornick et al., 2004).

However, this is not the situation in most developing countries, which lack resources for effective wastewater treatment facilities; hence, large volumes of wastewater generated, especially in urban areas, remain untreated. Estimates show median levels of treated wastewater to be about 35 per cent in Asia, 14 per cent in Latin America and not even 1 per cent in sub-Saharan Africa (WHO, 2000). This treatment is often minimal or partial (primary level) and the effluent quality is poor. Therefore, in these countries, partially treated wastewater from the few existing treatment systems and large amounts of untreated wastewater are discharged into urban drainage systems and natural waterways, which farmers end up using on their farms. A recent survey suggests that wastewater without any significant treatment is used for irrigation purposes in and around four out of five cities in the developing world (Raschid-Sally and Jayakody, 2008). Hence, while source treatment of wastewater is important, implementing supplementary, or in the worst case alternative, on-farm measures appears, for the time being, to be a realistic approach to reduce health risks posed by wastewater irrigation. 
In the following sections some simple measures are described that have been tested on leafy vegetables such as lettuce and spring onions, which are commonly eaten raw as salad or part of urban fast food. Measures include the use of alternative sites for agricultural production, alternative water sources, different types of pond systems, low-cost filtration, improved ways of water fetching and application, and the choice of alternative crops. Examples refer in most cases to detailed studies in Ghana, supported by field studies in Burkina Faso, Senegal, Togo and India.

\section{ON-FARM WATER TREATMENT MEASURES}

The WHO (2006) describes measures for risk reduction outside conventional wastewater treatment facilities which might be called 'post-treatment' or 'nontreatment' options (see Chapter 2). The term 'non-treatment' suits measures such as drip irrigation but not those measures which transfer conventional treatment processes to the farm. Pond-based systems are an example as ponds alone or in combination can be of very different sizes (down to $2-4 \mathrm{~m}^{3}$ ), fitting even small farms.

\section{Pond-based systems}

Pond systems are widely used as simple biological wastewater treatment systems in many low-income countries as they are cheaper than most conventional systems. In ponds, helminth eggs and protozoa cysts are mainly removed by sedimentation (Sperling et al., 2004), while pathogenic bacteria and viruses are removed by a combination of various factors that create an unfavourable environment for their survival (Curtis et al., 1992). However, in drier climates evaporation can cause the salinity of the pond water to increase, which makes it less suitable for cultivation (Clemett and Ensink, 2006). In addition, pond systems can be important breeding sites for mosquitoes, which are vectors for a number of diseases.

\section{Waste storage and treatment reservoirs (WSTR)}

WSTR have traditionally been used as storage reservoirs for pre-treated wastewater from waste stabilization ponds (WSP) intended for irrigation use (Mara, 2004). During storage, further pathogen removal is achieved (Athyde-Junior et al., 2000; Cifuentes et al., 2000). Guidelines for designing WSTRs are detailed in Juanicó and Dor (1999) and Mara (2004). The use of a three batch-fed pond system (fill-restuse) has shown best results for pathogen removal (Mara et al., 1996). Sometimes called the 'Chinese three-tank' system, at any one time, one tank is being filled by the farmer, one is settling and the settled water from the third is being used for irrigation. It requires a one-day period of quiescent settling to remove almost all 
helminth eggs and achieve a 1-2 log reduction of other pathogens. In general, when WSTR are properly designed, operated and maintained, they can achieve a 2-4-log unit removal of viruses, a 3-6 log unit removal for bacteria pathogens and 100 per cent removal for helminth eggs (Juanicó and Milstein, 2004; WHO, 2006).

\section{Simple on-farm sedimentation ponds}

In Ghana, as in many other countries in West Africa, shallow dugout ponds, which are usually about $1 \mathrm{~m}$ deep and have a surface area between 2 and $6 \mathrm{~m}^{2}$, are widely used at urban irrigated vegetable farming sites. In most cases, they are used as storage reservoirs that surface run-off and wastewater effluents are channelled into (Figure 10.1). Other variations include the use of mobile drums or concrete structures. Ponds are common in areas where irrigation water sources are far away. Farmers fill them manually or by pumping water from streams or tube wells. The key advantage of the ponds is the reduced walking distance, especially where watering cans are used. Depending on the size of the reservoir and irrigation frequency, refilling is done after one or several days. While the water is stored, sedimentation takes place and studies in Ghana showed that these ponds are very effective in removing helminths (reduced to less than one egg per litre) when sedimentation is allowed for two to three days. Removal of faecal coliforms in the same period was about $2 \log$ units. In contrast to the reduction of worm eggs, the die-off of coliforms was only significant during the dry season.

Digging a pond requires up to two man-days. With an additional plank to stand on (see below) the cost might be around US\$20. The installation costs would be higher where concrete ponds are used as is common in other parts of West Africa (Figure 10.2). There are different measures possible that can enhance sedimentation in these ponds like using natural flocculants and means to optimize pathogen die-off. These measures could help further to lessen the pathogen load in these mini-ponds.

\section{Filtration techniques}

There is a wide range of filtration systems that can be used for treating irrigation water (Morel and Diener, 2006). For on-farm installation, sand-filters with slow application rates (slow sand-filters) are a possible option. However, sand should be of correct configuration i.e. effective size (ES) of $0.15-0.40 \mathrm{~mm}$ and uniformity coefficient (UC) of 1.5-3.6 (Metcalf and Eddy, Inc., 1995). Sand-filters remove pathogenic micro-organisms from polluted water by first retaining them in the filtration media before they are eliminated (Stevic et al., 2004). Retention is achieved mainly through straining, in which larger micro-organisms (protozoans and helminths) are physically blocked as they move through the well-packed filter media, and adsorption, in which smaller ones like bacteria get attached to the 


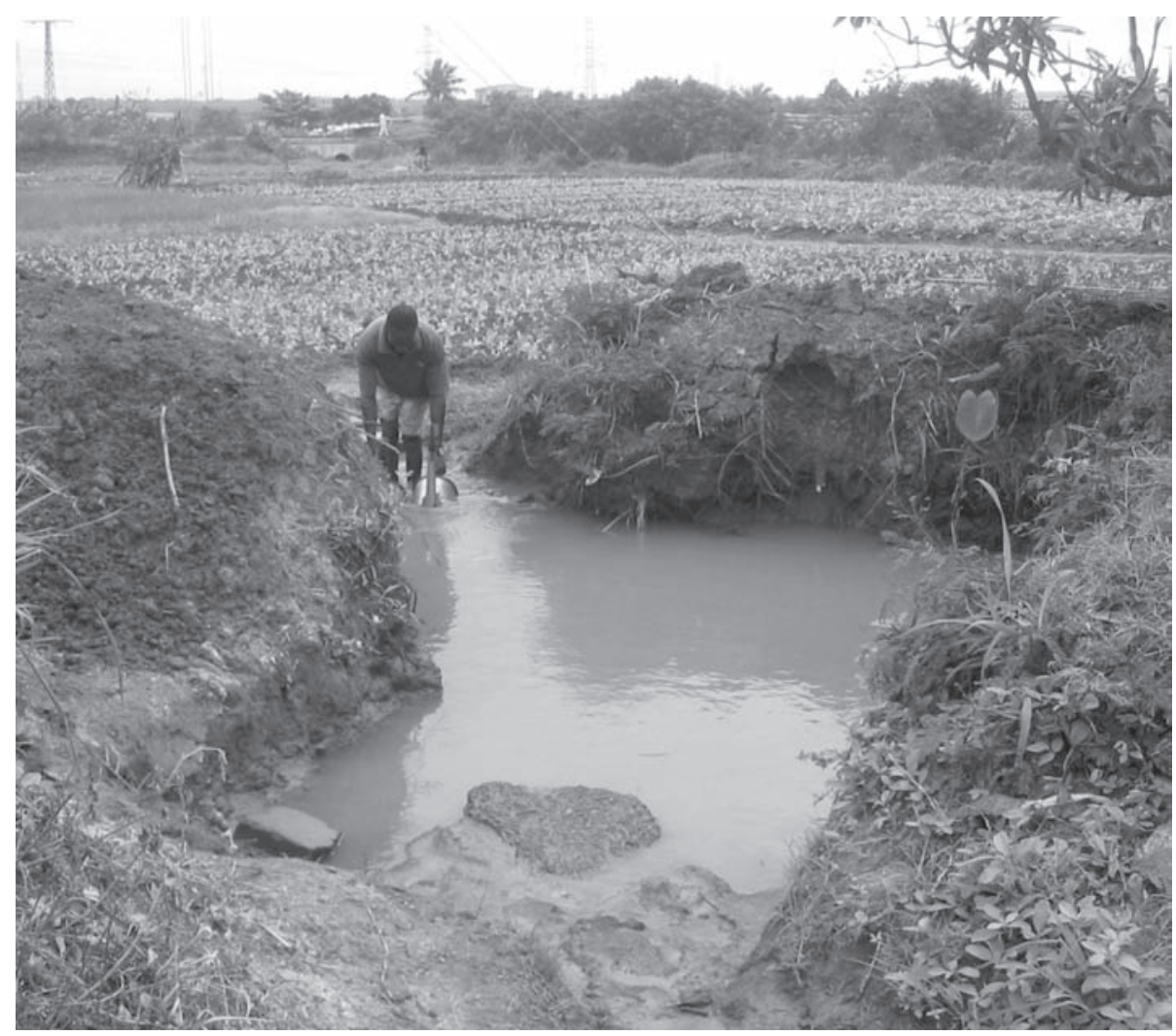

Figure 10.1 One of several dugout ponds farmers are using on informal urban vegetable farms in Kumasi, Ghana

filtration media. Elimination of pathogenic micro-organisms is achieved mainly by exposing them to unfavourable environmental conditions such as high temperature and also through predation by other organisms like protozoans. Similarly to manmade sand-filters, soils can act as natural bio-filters, especially if smaller textures (silt, clay) are dominant.

The typical pathogen removal range reported by the WHO based on a review of several studies for slow sand-filters is $0-3 \log$ units and 1-3 log units for bacteria and helminths respectively (WHO, 2006). Studies in Ghana using $0.5-1 \mathrm{~m}$ deep columns filled with uniform sand of mean ES of $0.17 \mathrm{~mm}$ and UC 3.6 achieved over 98 per cent of bacteria removal, equivalent to an average of $2 \mathrm{log}$ units per 100ml, and 71-96 per cent of helminths were removed (Keraita et al., 2008 b). This removal was significant but not adequate as irrigation water had very high initial levels of indicator organisms. For an urban vegetable farm of 0.1 ha, a column sand-filter with a surface area of $0.4 \mathrm{~m}^{2}$ placed on a simple stand and with 


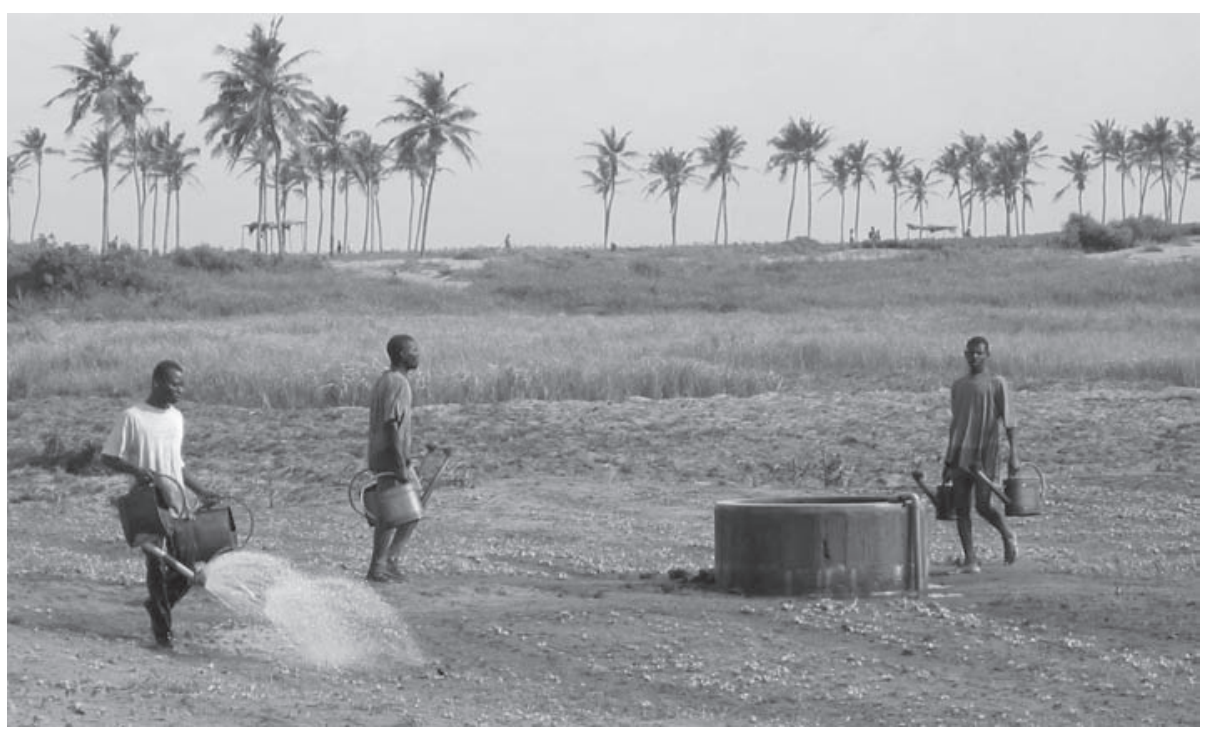

Figure 10.2 Concrete reservoir used by smallholders in Lomé, Togo. Ponds are interconnected through tubes and filled with a pump from a tube well; at other locations, also from streams

a water-storage tank costed about US\$100. This amount was less than 5 per cent of the average net revenue made by farmers if the system could be used for five years or more. The greatest limitation of sand-filters is clogging which farmers can address e.g. via a textile pre-filter to remove debris.

Farmers in West Africa also use other forms of infiltration systems. In Ouagadogou, Burkina Faso, wells are sunk next to wastewater canals, creating a hydraulic gradient which enables canal water to infiltrate the soil layer towards the well. In doing that, filtration takes place, leading to a reduction in micro-organisms and turbidity. Wastewater can also be allowed to pass through sand-filter trenches, sand embankments, column sand-filters and simple sandbags as farmers channel irrigation water to collection storage ponds. These types of filter will mostly affect protozoa and helminths. In Togo, Ghana and Senegal, farmers use different forms of sieves, but mostly folded mosquito nets on the watering-can intake hole to prevent particles like algae, waste and organic debris from entering the watering cans (Figure 10.3). In doing that, some pathogens adsorbed to organic matter are removed. Studies on this kind of simple filter system showed about 1 log unit removal for bacteria and 12-62 per cent for helminths when a normal nylon cloth material was used (Keraita et al., 2008b). Filtration materials can also be attached to irrigation equipment such as pumps. In all cases it is recommended to fine-tune the mesh size to find the best balance between easy water fetching and maximal debris filtration. As farmers are already used to these types of coarse filter systems 


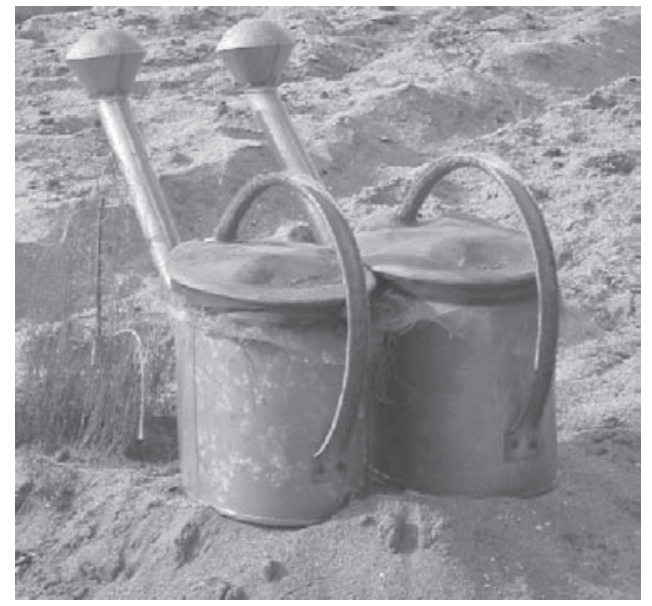

Figure 10.3 Watering cans with mosquito mesh to avoid debris (Dakar, Senegal)

to eliminate visible obstacles, an opportunity exists for adaptive field studies with high adoption potential.

\section{Use of irrigation infrastructure}

Irrigation infrastructure such as water reservoirs and weirs in irrigation canals can facilitate pathogen removal. Though not designed for this purpose, water-storage reservoirs can enhance sedimentation of helminths and bacterial die-off, especially in drier climates. Weirs, which are used for regulating irrigation water, act as traps for helminth eggs. A study done along the Musi river in Hyderabad, India, showed that irrigation infrastructure (mainly weirs, see Figure 10.4) can significantly improve water quality (Ensink et al., 2006). In the study, no helminth eggs were found $40 \mathrm{~km}$ downstream from where 133 eggs/litre were reported at a point on the Musi river closest to the city. Corresponding E. coli levels showed a reduction by 5 $\log$ units from $7 \log$ units per $100 \mathrm{ml}$ of water. Similar systems can be observed at micro-level where farmers block wastewater streams to create in-stream ponds (with overflow) for water fetching. In some instances, whole cascades of such barriers can be found (IWMI, 2008).

\section{IMPROVED WATER FETCHING AND APPLICATION MEASURES}

\section{Fetching of irrigation water}

In tests in Ghana, careful collection of irrigation water with a watering can, that did not disturb the sediment at the collection point in the stream or dugout, reduced 


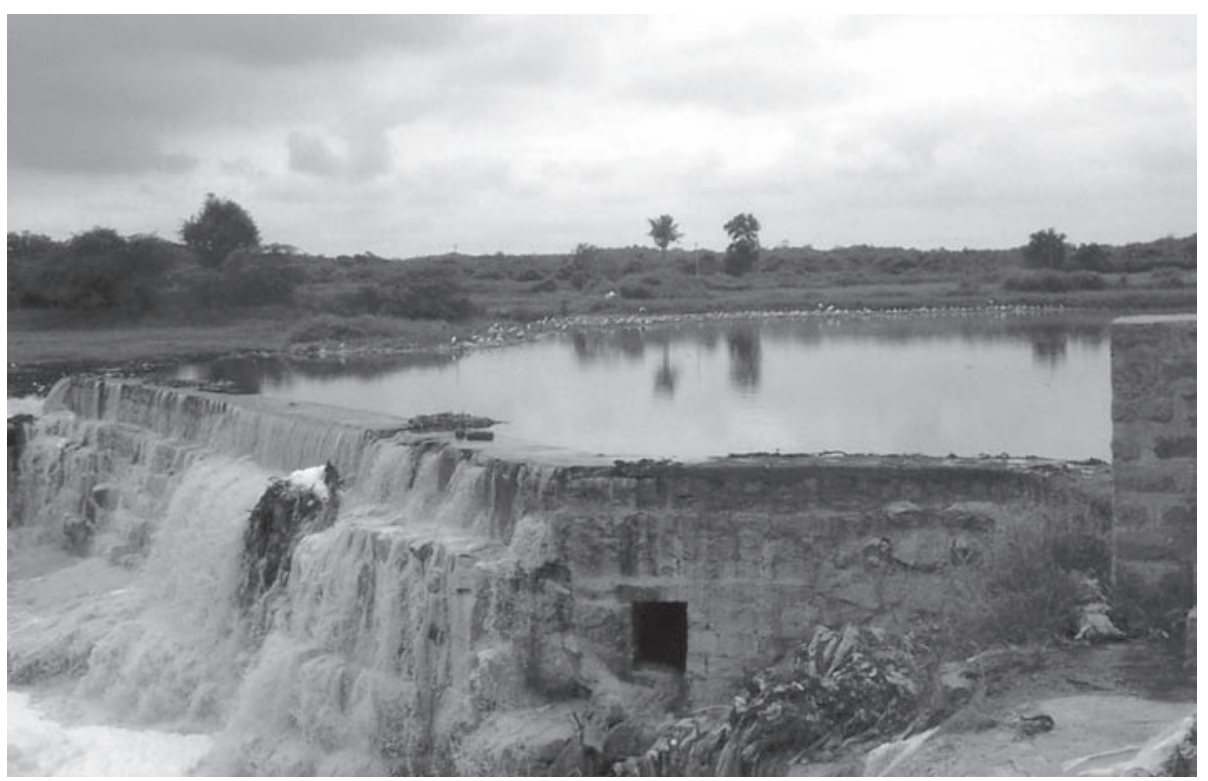

Figure 10.4 Weir in the Musi river, downstream of Hyderabad, Andhra Pradesh, India

helminth egg counts in irrigation water by 70 per cent. Most eggs settled on the first day of sedimentation. After three days without disturbance of the pond the average number of eggs in the pond water was less than one egg per litre (Keraita et al., 2008a). However, farmers in Ghana have to irrigate continuously due to high temperatures and use the dugouts regularly in the morning and afternoon on most sunny days without rain, thereby disturbing the water continuously. This could be avoided with a set of ('Chinese three-tank') dugouts as described above. Another option is the use of a wooden log across the pond to avoid entering the water (Figure 10.5). Water can also be fetched with a watering can connected to a rope, removing the need to step into the pond or stream (Figure 10.6). Deeper pond designs prevent the watering can from touching the sediment layer during water fetching (Drechsel et al., 2008). Investment costs are limited to labour (especially if a Chinese three-tank system is used) and the required behaviour-change during water fetching.

Water from irrigation channels along the Musi River in India is pumped onto fields. The foot valve apparatus at the inlet pipe is usually heavy, which helps to keep the pipe in place under water. In many instances the pipe touches the sludge layer in the canal and sediments are sucked in, increasing the risk of metal and helminth egg contamination. U-shaped pump ends (Figure 10.7) could reduce this threat (Luque Ruiz, 2009). 


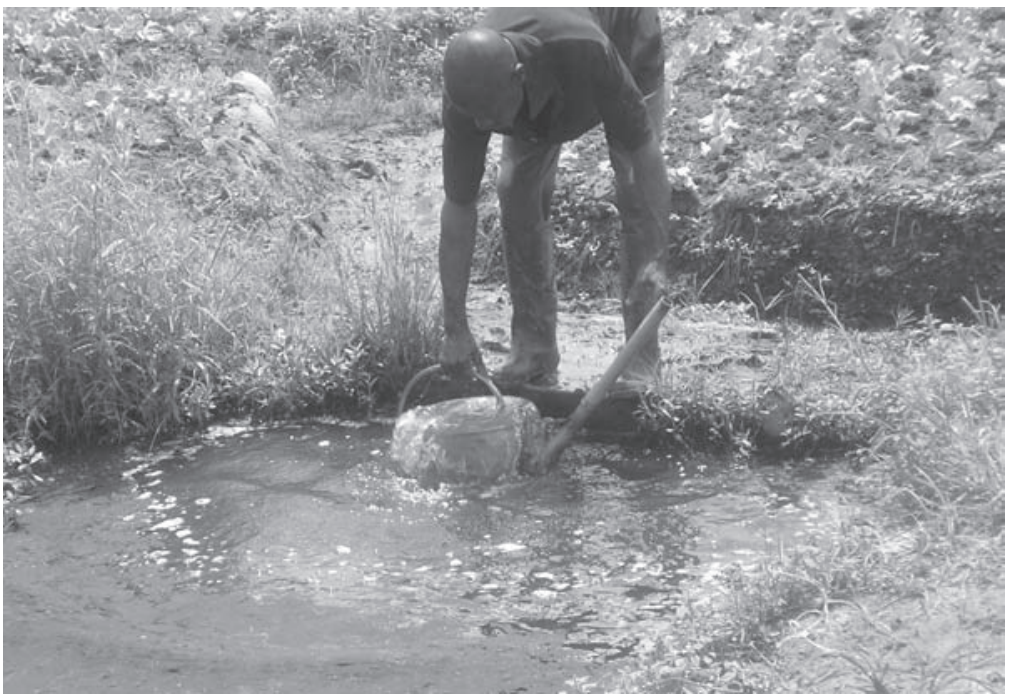

Figure 10.5 Farmer standing on a wooden log while fetching water from a small dugout pond (Kumasi, Ghana)

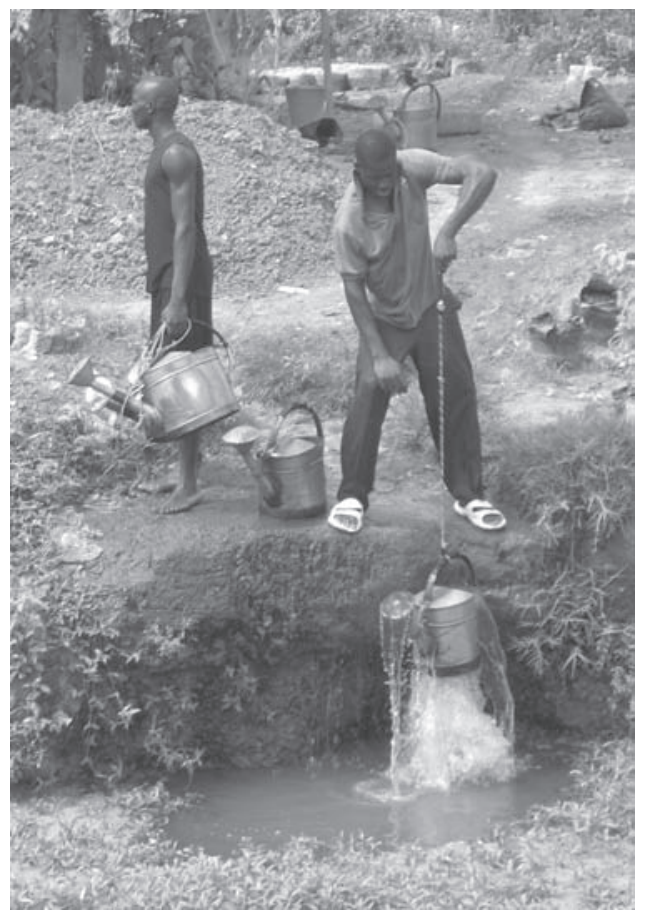

Figure 10.6 Farmer fetching water with a can on a rope from a wastewater stream (Ouagadougou, Burkina Faso) 


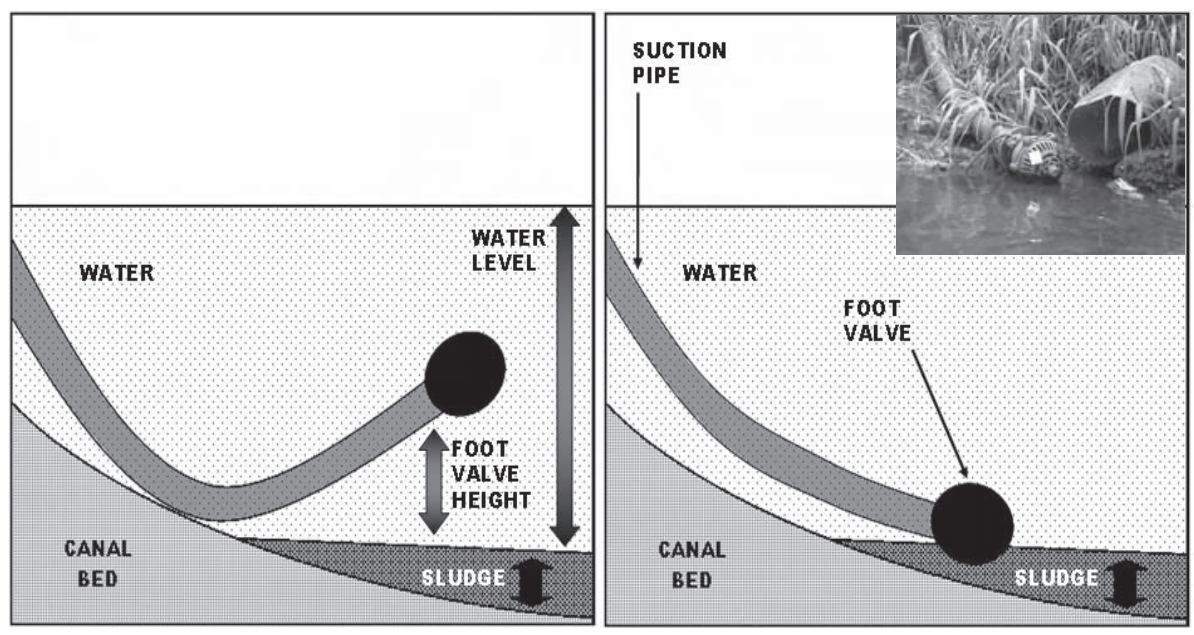

Figure 10.7 Lifting pumps inflow valves out of the sediment of irrigation channels near Hyderabad, India

\section{Irrigation methods}

With regard to reducing crop contamination, good irrigation methods should minimize contact between the edible parts of the plant and contaminated irrigation water. Overhead irrigation methods such as sprinkler irrigation and watering cans have the highest potential to transfer pathogens to leafy vegetables as water is applied on edible parts and due to the wider movement of pathogens through aerosols (Pescod, 1992). Flood and furrow irrigation methods apply water on the surface and are less likely to contaminate high growing crops; but for low-lying crops and root crops contamination is still high. Localized techniques, such as drip irrigation, have minimal pathogen transfer to crop surfaces because water is directly applied to the roots (Pescod, 1992).

Several studies have been conducted on the effects of sprinkler, drip (both surface and subsurface) and furrow irrigation on crop contamination (Armon et al., 2002; Bastos and Mara, 1995; El Hamouri et al., 1996; Oron et al., 2001; Solomon et al., 2002). The studies show that drip irrigation results in comparatively lower contamination on crops than furrow and sprinkler irrigation. However, drip kits, as promoted in developed countries, are very expensive and prone to clogging as polluted water usually has high turbidity levels (Capra and Scicolone, 2007; Martijn and Redwood, 2005). Nevertheless, low-cost drip irrigation techniques like bucket drip kits (Figure 10.8) (sacks can also be used) have shown a high potential for use and adoption in low-income countries (Kay, 2001). Similar to more sophisticated kits, the low-cost types promoted, for example, by International Development Enterprises (IDE) in India can be tailored to local vegetable-bed 


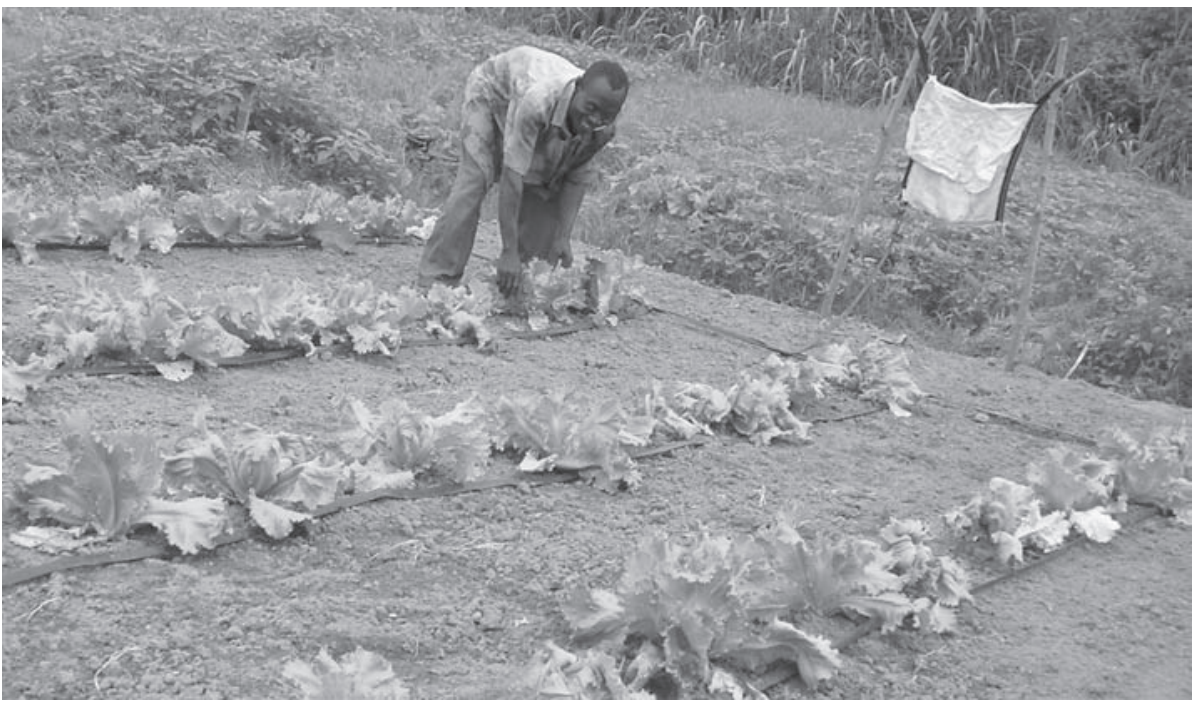

Figure 10.8 Simple drip irrigation kit made in India and tested in Ghana for lettuce. Adjustments are needed to increase the planting density

sizes. Studies done in Ghana using bucket drip kits showed higher reduction in contamination (up to $6 \log$ units) especially during the dry season (Keraita et al., 2007b) as compared to the often cited 2-4 log units (WHO, 2006).

There are hardly any documented studies on traditional or modified traditional irrigation methods involving watering cans, buckets, subsurface clay pods or calabashes in relation to crop contamination. Studies in Ghana showed a great potential in reducing vegetable contamination by modifying the handling of watering cans to reduce splashing of contaminated soils on to the crops. Using a watering can with an outflow rose (a cap with holes in) and watering from a height $<0.5 \mathrm{~m}$ (Figure 10.9) reduced thermotolerant coliforms by $2.5 \mathrm{log}$ units and helminths by 2.3 eggs per $100 \mathrm{~g}$ of lettuce compared with using a watering can with no end cap, from a height $>1 \mathrm{~m}$ (Keraita et al., 2007a). The required changes are of very low cost, but further studies are needed to verify the effectiveness on different types of soil and crop cover.

\section{Scheduling of water application}

Timing of irrigation, including frequency, is not only important for pathogen reduction but also for reducing salinity. One of the most widely documented field water-management measures to reduce pathogens is cessation of irrigation, in which irrigation is stopped a few days before crops are harvested. This results in 


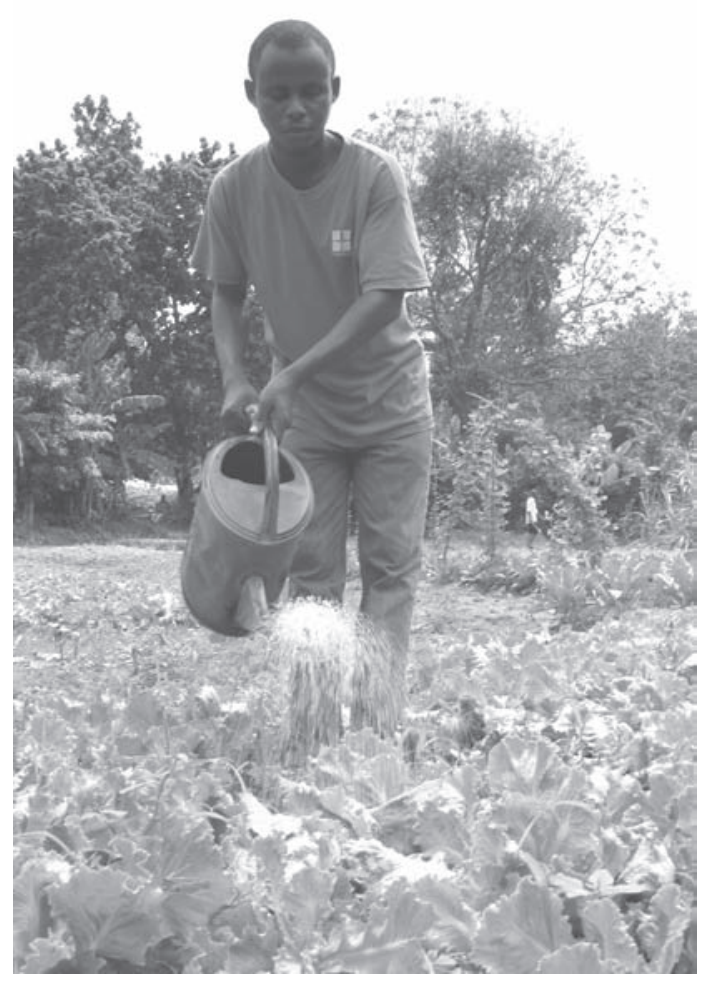

Figure 10.9 Holding the watering can at low height and using an outflow rose reduces splashing of already contaminated soil on the crop (Kumasi, Ghana)

exposure to conditions that are unfavourable to pathogen growth including heat, desiccation and sunlight (Shuval et al., 1986). Studies have provided some ranges of potential survival times for pathogens on crops, soils and water in temperate and tropical climates (see Table 12.2, Chapter 12), along with identifying how environmental conditions influence pathogen survival (Feachem et al., 1983; Shuval et al., 1986; Yates et al., 1987). In short, pathogen inactivation on crops is more rapid in hot, sunny weather than in cool, cloudy or rainy conditions.

WHO (2006) gives a pathogen die-off range of between 0.5 and $2 \mathrm{log}$ units per day between final irrigation to consumption, while Fattal et al. (2004) use 3 log units in their risk-assessment models. In another study, it was revealed that when trickling filter effluent with $10^{6}$ thermotolerant coliforms per $100 \mathrm{ml}$ was used to spray-irrigate lettuces, initial concentrations of indicator bacteria exceeded $10^{5}$ thermotolerant coliforms per $100 \mathrm{~g}$ fresh weight. Once irrigation ceased, no Salmonella could be detected after five days, and the levels of thermotolerant coliforms after 7-12 days were comparable to those detected on lettuces irrigated 
with freshwater (Vaz da Costa-Vargas et al., 1996). In Ghana, studies from field trials showed an average daily reduction of $0.65 \mathrm{log}$ units of thermotolerant coliforms on lettuce (Keraita et al., 2007a). However, they also showed that cessation in hot climates has correspondingly high yield losses (1.4 tons/ha of fresh weight) that may make it harder for farmers to adopt the method. Indeed, in Accra or Kumasi, farmers irrigate lettuce preferably twice a day, while in the cooler Addis Ababa lettuce is irrigated thrice a week, which offers greater possibility for die-off.

Enforcement of irrigation cessation in hot climates has raised reservations that some crops, especially leafy vegetables and salad crops, will lose their freshness and thereby their market value (Vaz da Costa-Vargas et al., 1996). It has been suggested that irrigation cessation should be used for fodder crops that do not have to be harvested at the peak of their freshness (Blumenthal et al., 2000). As much as 99 per cent elimination of detectable viruses has been reported after two days' exposure to sunlight, supporting regulations of a suitable time interval between irrigation and crop-handling or grazing time (Feigin et al., 1991). Enforcement can be difficult especially where vegetable farming is an informal activity and not regulated, as is the case in many low-income countries. In addition, in countries like Ghana, where farmers do not market the vegetables they produce but wait for vegetable traders to visit their fields and select the crops they like, special arrangements will have to be made with the traders for successful timing of the measure (Keraita et al., 2007a).

\section{Crop SELECTION}

Some crops are more prone to contamination from pathogens than others. For example, crops with their edible parts more exposed to contaminated soils and irrigation water like low-growing leafy vegetables or root crops (e.g. carrots) will be more prone to pathogen contamination. The WHO, in its Guidelines for safe use of wastewater in agriculture, advises crop restrictions, especially for crops eaten raw (WHO, 2006). However, a shift in the type of crops planted is only feasible if the market value of the alternative crops is similar. Crop restrictions can be hard to implement if necessary conditions such as law enforcement, market pressure and demand for cleaner vegetables are not in place. So while there have been successful crop-restriction schemes in India, Mexico, Peru and Chile (Blumenthal et al., 2000; Buechler and Devi, 2003), this has not been possible in other countries where wastewater irrigation is informal, such as in sub-Saharan Africa.

\section{ALTERNATIVE FARMLAND AND/OR SAFER IRRIGATION WATER}

Wastewater use could be reduced if authorities have the possibility to provide farmers with safer irrigation water or an alternative location where water is not 
polluted. In Accra, Ghana, for example, groundwater was found at a convenient depth for treadle pumps, but the water was saline due to salt intrusion from the sea. In other cities, the groundwater level was in many sites too deep (more than $15 \mathrm{~m}$ ) to make borehole drilling an economic option for farmers. However, Ghana's Ministry of Food and Agriculture extended their national initiative to support small-scale irrigation and started borehole drilling on several urban farming sites. This risk-mitigation strategy was apparently successful in Benin where the city authorities of Cotonou and Seme-Kpodji and various national ministries agreed to allocate about 400 ha of alternative farmland to urban farmers. The new site has shallow non-saline groundwater, which can easily be lifted by treadle pump for allseason irrigation. About 1000 farmers declared their interest to move to this periurban site despite its distance from the urban markets (Drechsel et al., 2006).

\section{ENHANCING ADOPTION OF RISK-REDUCTION MEASURES}

Many initiatives to address wastewater irrigation-related health risks in lowincome countries remain at the risk-assessment level or pilot stage. To have the desired impact, recommended measures have to be integrated into routine farming practice. In this section, practical experience of some approaches is shared, drawing on several interlinked 'wastewater projects' conducted in Ghana between 2004 and 2009. The projects were supported by the Knowledge Sharing in Research project of the Consultative Group on International Agricultural Research (CGIAR). More details and lessons can be found in Chapters 16 and 17.

\section{Innovative knowledge sharing}

The project in Ghana encouraged and facilitated knowledge exchanges among farmers as well as between farmers and scientists. Research findings were synthesized according to the expressed wishes of the extension service to make them as userfriendly as possible. The materials illustrated safer irrigation practices and were translated into different regional languages. They included training media (radio and video) for extension offices and farmers as well as illustrated flip-charts/posters. In addition, the project prepared modules for farmer field schools, to actually demonstrate best practices. The module preparation was supported by the Food and Agriculture Organization (FAO) and involved farmers' representatives, extension officers from the Ministry of Food and Agriculture and communication experts. To enhance communication along the farm to fork pathway, all key stakeholders took part in so-called 'road shows', allowing them to follow the crops from the farm to the kitchen to observe and discuss sources of risks and options for risk reduction, and to understand the necessity of a multiple-barrier approach. 


\section{Involving authorities}

Equally important is to involve local authorities and relevant government ministries from the initial stages. In Ghana, the project involved local authorities, the Ministry of Food and Agriculture, the private sector interested in food safety and other relevant agencies such as food-safety regulators. Some of them were involved as research partners, others coordinated training events which incorporated project results, and others were kept updated through policy briefs and participation in project meetings. The latter applies in particular to those agencies setting policies and regulations for wastewater reuse, and aids the institutionalization of safe practices. They also have a mandate to offer extension services to farmers. Dissemination of safe practices developed during the project will be done by the extension officials from the Ministry of Food and Agriculture. The target is to incorporate safer irrigation practices in the ministries extension and training curricula.

\section{Linking with other projects}

Waste reuse projects should also be linked to other relevant projects or government projects with common goals. These could include government poverty-reduction programmes for the urban poor, initiatives for urban food security, nutritional programmes that emphasize consumption of green vegetables, health programmes and ongoing policy revisions. In Ghana, the project results influenced the Irrigation Policy launched in 2008 and the currently ongoing agricultural byelaw revision in the capital city, Accra. As wastewater use is just one of the routes by which excretarelated diseases are transmitted in poor communities, improved irrigation practices might not have much effect on the occurrence of intestinal infections when sanitation or hygiene remains unimproved. In such situations, linking vegetablewashing with a handwashing campaign might be very cost-effective.

\section{Incentives}

To enhance adoption of safer practices in waste reuse, farmers will need some form of incentive. This applies to most forms of behaviour-change, but in particular to situations where recommended practices involve increased inputs, such as personal labour. Studies have shown that people are more likely to adopt innovations if they get direct benefits for themselves rather than for the general population (Frewer et al., 1998). On this basis, incentives are even more important as the main beneficiaries are not the farmers but the consumers of their produce (exotic vegetables produced are for sale, not for farm household consumption). The most obvious incentive for farmers to adopt safe practices would be higher economic returns for safer vegetables. If a related market demand exists, producer groups 
could be encouraged to sell their products outside the existing marketing channels to avoid mixing-up safe and unsafe produce. This could be done by linking farmers directly to large unit consumers like hotels and designated selling-points of safe produce in markets and supermarkets or hotels. Other incentives could be institutional support from government institutions like the provision of extension services for training farmers, loans, awards and land-tenure security. Certification standards and labelling could be steps in the medium term. The media should be partners in these efforts to promote good practices and recognize progressive farmers. More details are presented in Chapter 16.

\section{CONCLUSIONS}

Farm-based measures can contribute to the reduction of health risks deriving for consumers from irrigated agriculture. These measures should play a complementary role to wastewater treatment and other post-harvest measures to comprehensively reduce risks associated with wastewater irrigation. Unfortunately, farm-based measures have not yet received the needed attention in research, perhaps due to the traditional focus on conventional wastewater treatment as the best solution for health protection. Although many principles of wastewater treatment could also be applied on farm, field-testing of these measures is scarce and their potential to reduce health risks is relatively unknown or not yet fully proven. There is an urgent need for scientists to work with farmers to adapt the technologies and improve their efficiency in pathogen removal.

Assessments to provide evidence for health-risk reduction are also needed. These are particularly important and urgent in high-risk areas like urban vegetable farming in developing countries where farmers often have no other choice than using untreated wastewater for irrigation. A key challenge for the adoption of farm-based measures is that they require behaviour-change without obvious and direct benefit. This requires incentive systems which can range from supporting market demand to social marketing. It also requires that farmers are equipped with knowledge on health risks and can rely on institutional support, like from the extension service.

The options of farm-based measures for health-risk reduction presented here are biased to experiences gained in West Africa. There, watering cans are extensively used in urban vegetable production while in other regions, such as Eastern Africa, topography favours gravity-flow and furrow or flood irrigation systems. Which measures fit (alone or in combination) a particular situation, will depend on local site characteristics and practices. Further studies are required to address other smallholder irrigation systems and crops to develop new measures or adapt the ones presented here. 


\section{REFERENCES}

Armon, R., Gold, D., Brodsky, M. and Oron, G. (2002) 'Surface and subsurface irrigation with effluents of different qualities and presence of Cryptosporidium oocysts in soil and on crops', Water Science and Technology, vol 46, no 3, pp115-22

Athyde-Junior, G. B., Mara, D. D., Pearson, H. W. and Silva, S. A. (2000) 'Faecal coliform die-off in wastewater storage and treatment reservoirs', Water Science and Technology, vol 42, no 10, pp139-47

Bastos, R. K. X. and Mara, D. D. (1995) 'The bacterial quality of salad crops drip and furrow irrigated with waste stabilization pond effluent: An evaluation of WHO Guidelines', Water Science and Technology, vol 12, pp425-30

Blumenthal, U. J., Peasey, A., Ruiz-Palacios, G. and Mara, D. D. (2000) Guidelines for Wastewater Reuse in Agriculture and Aquaculture: Recommended Revisions Based on New Research Evidence, Task No 68, Part 1, WELL Study, London School of Hygiene and Tropical Medicine, London / Loughborough University, Loughborough

Buechler, S. and Devi, G. (2003) 'Household food security and wastewater dependent livelihood activities in Andhra Pradesh, India', unpublished background document prepared for the WHO Guidelines (2006)

Capra, A. and Scicolone, B. (2007) 'Recycling of poor quality urban wastewater by drip irrigation systems', Journal of Cleaner Production, vol 15, pp1529-34

Cifuentes, E., Blumenthal, U., Ruiz-Palacios, G., Bennett, S. and Quigley, M. (2000) 'Health risk in agricultural villages practicing wastewater irrigation in Central Mexico: Perspectives for protection', in I. Chorus, U. Ringelband, G. Schlag and O. Schmoll (eds) Water Sanitation and Health, IWA Publishing, London, pp249-56

Clemett, A. E. V., and Ensink, J. H. J. (2006) 'Farmer driven wastewater treatment: A case study from Faisalabad, Pakistan', Conference Proceedings from the 32nd WEDC International Conference on Sustainable Development of Water Resources, Water Supply and Environmental Sanitation, WEDC, Colombo

Curtis, T. P., Mara, D. D. and Silva, S. A. (1992) 'Influence of $\mathrm{pH}$, oxygen and humic substances on ability of sunlight to damage faecal coliforms in waste stabilization ponds', Applied Environmental Microbiology, vol 58, pp1335-43

Drechsel, P., Graefe, S., Sonou, M. and Cofie, O. (2006) Informal Irrigation in Urban West Africa: An Overview, Research Report no 102, IWMI, Colombo, www.iwmi.cgiar. org/Publications/IWMI_Reports/PDF/pub102/RR102.pdf

Drechsel, P., Keraita, B., Amoah, P., Abaidoo, R., Raschid-Sally, L. and Bahri, A. (2008) 'Reducing health risks from wastewater use in urban and peri-urban sub-Saharan Africa: Applying the 2006 WHO Guidelines', Water Science and Technology, vol 57, no 9, pp1461-6

El Hamouri, B., Handouf, A., Mekrane, M., Touzani, M., Khana, A., Khallayoune, K. and Benchokroun, T. (1996) 'Use of wastewater for crop production under arid and saline conditions: Yield and hygienic quality of crop and soil contaminations', Water Science and Technology, vol 33, nos 10-11, pp327-34

Ensink, J. H. J., Brooker, S., Cairncross, S. and Scott, C. A. (2006) 'Wastewater use in India: The impact of irrigation weirs on water quality and farmer health', Conference Proceedings from the 32nd WEDC International Conference on Sustainable Development of Water Resources, Water Supply and Environmental Sanitation, WEDC, Colombo 
Fattal, B., Lampert, Y. and Shuval, H. (2004) 'A fresh look at microbial guidelines for wastewater irrigation in agriculture: A risk-assessment and cost-effectiveness approach', in C. A. Scott, N. I. Faruqui and L. Raschid-Sally (eds) Wastewater Use in Irrigated Agriculture: Confronting the Livelihood and Environmental Realities, CABI Publishing, Wallingford, UK pp59-68

Feachem, D. G., Bradley, D. J., Garelick, H. and Mara, D. D. (1983) Sanitation and Disease: Health Aspects of Excreta and Wastewater Management, John Wiley and Sons, Bath

Feigin, A., Ravina, I. and Shalhevet, J. (1991) Irrigation with Treated Sewage Effluent: Management for Environmental Protection, Springer Verlag, Heidelberg

Frewer, L. J., Howard, C. and Shepherd, R. (1998) 'Understanding public attitudes to technology', Journal of Risk Research, vol 1, no 3, pp221-35

Hoek, W. van der, Tuan Anh, V., Dac Cam, P., Vicheth, C. and Dalsgaard, A. (2005) 'Skin diseases among people using urban wastewater in Phnom Penh', Urban Agriculture Magazine, vol 14, pp30-31

Hoek, W. van der, Ul Hassan, M., Ensink, J. H. J., Feenstra, S., Raschid-Sally, L., Munir, S. and Aslam, M. R. (2002) Urban Wastewater: A Valuable Resource for Agriculture, International Water Management Institute Research Report 63, IWMI, Colombo

IWMI (2008) 'Health risk reduction in a wastewater irrigation system in urban Accra, Ghana', www.youtube.com/watch?v=f_EnUGa_GdM

Jiménez, B. and Asano, T. (2008) Water Reuse: An International Survey, Contracts, Issues and Needs around the World, IWA Publishing, London, p648

Juanicó, M. and Dor, I. (1999) Hypertrophic Reservoirs for Wastewater Storage and Reuse: Ecology, Performance, and Engineering Design, Springer Verlag, Heidelberg

Juanicó, M. and Milstein, A. (2004) 'Semi-intensive treatment plants for wastewater reuse in irrigation', Water Science and Technology, vol 50, no 2, pp55-60

Kay, M. (2001) Smallholder Irrigation Technology: Prospects for Sub Saharan Africa, IPRTRID, FAO, Rome

Keraita, B., Drechsel, P. and Konradsen, F. (2008a) 'Using on-farm sedimentation ponds to reduce health risks in wastewater irrigated urban vegetable farming in Ghana', Water Science and Technology, vol 57, no 4, pp519-25

Keraita, B., Drechsel, P. and Konradsen, F. (2008b) 'Potential of simple filters to improve microbial quality of irrigation water used in urban vegetable farming in Ghana', Journal of Environmental Science and Health, Part A, vol 43, pp749-55

Keraita, B., Konradsen, F., Drechsel, P. and Abaidoo, R. C. (2007a) 'Reducing microbial contamination on lettuce by cessation of irrigation before harvesting', Tropical Medicine and International Health, vol 12, no 2, pp8-14

Keraita, B., Konradsen, F., Drechsel, P. and Abaidoo, R. C. (2007b) 'Effect of low-cost irrigation methods on microbial contamination of lettuce', Tropical Medicine and International Health, vol 12, no 2, pp15-22

Luque Ruiz, F. J. (2009) 'Investigation of methods to reduce cadmium and helminth eggs in irrigated wastewater', MSc thesis (Water Science, Policy and Management), Oxford University, Oxford

Mara, D. D. (2004) Domestic Wastewater Treatment in Developing Countries, Earthscan, London 
Mara, D. D., Pearson, H. W., Oragui, J. I., Crawley, L. R., de Oliveira, R. and Silva, S. A. (1996) Wastewater Storage and Treatment Reservoirs in Northeast Brazil, TPHE Research Monograph no 12, University of Leeds, Department of Civil Engineering, Leeds

Martijn, E. and Redwood, M. (2005) 'Wastewater irrigation in developing countries - Limitations for farmers to adopt appropriate practices', Irrigation and Drainage, vol 54, pp63-S70

McCornick, P. G., Hijazi, A. and Sheikh, B. (2004) 'From wastewater reuse to water reclamation: Progression of water reuse standards in Jordan', in C. A. Scott, N. I. Faruqui and L. Raschid-Sally (eds) Wastewater Use in Irrigated Agriculture: Confronting the Livelihood and Environmental Realities, CABI Publishing, Wallingford, UK, pp113-25

Metcalf and Eddy, Inc. (1995) Wastewater Engineering: Treatment, Disposal and Reuse, McGraw-Hill, New York, p1819

Morel, A. and Deiner, S. (2006) Greywater Management in Low and Medium Income Countries; A Review of Different Treatment Systems for Households or Neighborhoods, EAWAG, Dübendorf, Switzerland

Oron, G., Armon, R., Mandelbaum, R., Manor, Y., Campos, C., Gillerman, L., Salgot, M., Gerba, C., Klein, I. and Enriquez, C. (2001) 'Secondary wastewater disposal for crop irrigation with minimal risks', Water Science and Technology, vol 43, no 10, pp139-46

Pescod, M. B. (ed) (1992) Wastewater Treatment and Use in Agriculture, Irrigation and Drainage Paper 47, FAO, Rome

Raschid-Sally, L. and Jayakody, P. (2008) 'Drivers and characteristics of wastewater agriculture in developing countries: Results from a global assessment, Colombo, Sri Lanka', IWMI Research Report 127, International Water Management Institute, Colombo

Shuval, H. I., Adin, A., Fattal, B., Rawitz, E., Yekutiel, P. (1986) Wastewater Irrigation in Developing Countries: Health Effects and Technical Solutions, World Bank Technical Paper no 51, World Bank, Washington, DC

Solomon, E. B., Potenski, C. J. and Matthews, K. R. (2002) 'Effect of irrigation method on transmission to and persistence of Escherichia coli O157:H7 on lettuce', Journal of Food Protection, vol 65, no 4, pp673-6

Sperling, M. von, Bastos, R. K. X. and Kato, M. T. (2004) 'Removal of E. coli and helminth eggs in UASB-polishing pond systems', Water Science and Technology, vol 51, no 12, pp91-7

Stevik, T. K., Aa, K., Auslan, G. and Hanssen, J. F. (2004) 'Retention and removal of pathogenic bacteria in wastewater percolating through porous media', Water Research, vol 38, pp1355-67

Vaz da Costa-Vargas, S., Bastos, R. K. X. and Mara, D. D. (1996) Bacteriological Aspects of Wastewater Irrigation, Dept. of Civil Engineering, Tropical Public Health Engineering, University of Leeds, Leeds

WHO (2000) Global Water Supply and Sanitation Assessment 2000 Report, World Health Organization (WHO) / United Nations Children's Fund (UNICEF), Geneva and New York

WHO (2006) Guidelines for the Safe Use of Wastewater, Excreta and Greywater, Volume 2: Wastewater Use in Agriculture, World Health Organization, Geneva

Yates, M. V., Yates, S. R., Wagner, J. and Gerba, C. P. (1987) 'Modeling virus survival and transport in the subsurface', Journal of Contaminant Hydrology, vol 1, pp329-45 